Canadian University Music Review

Canadian University Music Review

Revue de musique des universités canadiennes

\title{
The Refugee Composer in America: A Topic for Twentieth-Century Music History
}

\section{Alan Lessem}

Numéro 6, 1985

URI : https://id.erudit.org/iderudit/1014037ar

DOI : https://doi.org/10.7202/1014037ar

Aller au sommaire du numéro

\section{Éditeur(s)}

Canadian University Music Society / Société de musique des universités canadiennes

\section{ISSN}

0710-0353 (imprimé)

2291-2436 (numérique)

Découvrir la revue

Citer cet article

Lessem, A. (1985). The Refugee Composer in America: A Topic for

Twentieth-Century Music History. Canadian University Music Review / Revue de musique des universités canadiennes, (6), 222-238.

https://doi.org/10.7202/1014037ar

(c) Canadian University Music Society / Société de musique des universités canadiennes, 1985
Ce document est protégé par la loi sur le droit d'auteur. L'utilisation des services d'Érudit (y compris la reproduction) est assujettie à sa politique d'utilisation que vous pouvez consulter en ligne.

https://apropos.erudit.org/fr/usagers/politique-dutilisation/ 


\title{
THE REFUGEE COMPOSER IN AMERICA: A TOPIC FOR TWENTIETH-CENTURY MUSIC HISTORY
}

\author{
Alan Lessem
}

While the debt of twentieth-century American music and musical life to the influx of European composers, performers, and scholars before World War II has been generally recognized, the historical reality of this musical migration has not yet been carefully considered, nor its many ramifications. Among a number of studies which, in the last twenty years, have dealt with the intellectual and cultural migration at large, only a very few make more than a passing reference to musicians. ${ }^{1}$ Some surveys of American music, such as those of Gilbert Chase and Charles Hamm, do give space to immigrant composers, but only to point out the importance of their influence on the younger American generation. But a perspective one-sidedly American cannot do justice to the matter. The view of Hamm for example, that the Europeans served merely as vehicles for the dissemination and implantation of aesthetic values and musical techniques that they brought with them (see Hamm 1983: 552-55; 562), overlooks the complex character of the newcomers' adaptation to new conditions, as well as factors in American society and musical culture that stood in the way of a full absorption of European influences. Indeed, the question of such influences can only be answered after due attention has been given to the larger issue of immigrantAmerican relations, particularly since the ideas and attitudes of the Europeans, as solidly formed and stiffly aloof as they may at first have been, were gradually affected by the experience of cultural transfer. Americans, in encountering representatives of the old world who were taking root in the new, were therefore also looking at partial reflections of themselves.

It certainly cannot be denied that many of the refugee composers were reluctant, even after some years in the new 
country, to consider themselves as immigrants in any more than a technical sense. Aside from the odd exception, such as Kurt Weill, resistance to assimilation was proclaimed policy among established composers, and even younger ones who had already gained some recognition at home. America, for them, would provide little more than a physical refuge: in Ernst Krenek's words, "shelter, food and time to write music" (1941: 145). Neither Paul Hindemith nor Arnold Schoenberg conceded any larger significance to their changed circumstances. In Hindemith's view, environment may certainly shape the impressions of a young person, but "for more settled spirits, in their further working out of long established plans, the Rhine appears no more important than the Mississippi, the Connecticut valley or the Gobi desert."2 No less emphatic was Schoenberg's response to questions put to him by Albert Goldberg, the Los Angeles music columnist:

If immigration to America has changed me, I am not aware of it.... Maybe I would have written more when remaining in Europe, but I think nothing comes out, what was not in. And two times two equals four in every climate. Maybe I had four times harder to work for a living. But I made no concessions to the market. ${ }^{3}$

Such faith in the autonomy of creation from the outside world need certainly not go unquestioned, since it is itself historically conditioned. In this particular instance one may, furthermore, suggest that a psychological defence mechanism compensates for the trauma of dislocation by denying its effects. There may also be certain elements in the new milieu which spark resistance to it. Such appears to be the case with Schoenberg's just-cited reference to the "market." Here lies a clue to at least one larger consequence of the encounter with America, for it was not only Schoenberg whose ever more entrenched views appeared to Americans as representing a perhaps enviable but nevertheless disappearing order. The volte-face by which erstwhile modernists turned (overnight, as it were) into traditionalists was not really understood, at the time, for what it pointed to: namely, a sharp conflict between standards of what Europeans saw as belonging to to the sphere of "culture" and those, now only too prevalent, of business and the entertainment industry. In the Europe of the 1920 s the gap between the two had still been bridgeable. But modernist composers who had then been able to respond, in a lively manner, to the everyday musical milieu, assimilating 
(ironically enough) American-influenced popular music to their own compositional idioms through light-hearted and even affectionate parody, now found it necessary to protect themselves from what Schoenberg called, in disgust, an "amusement-arcade world."4 Even Stravinsky, for whom style and milieu had been quite inseparable during his Parisian years, now allowed himself only an occasional venture (notably with such works as the Ebony Concerto) beyond confines more and more tightly drawn. Yet such resistance was not provoked principally by aesthetic or moral criteria, as is evident in Schoenberg's admiration for Gershwin or Stravinsky's for Woody Herman; rather did it reflect the fear that the emerging and still fragile musical culture of America would become victim to the demands of the entertainment industry whose power was unchecked by any institutional structure of support for the arts. Krenek, for one, began to speak to his concern regarding this matter soon after setting foot in the country, as did Hindemith (see Krenek 1938). Some years later Hindemith used the platform of his Harvard lectures to attack the "germ" of entertainment which, he alleged, had so infected Americans with a craving for sensation that even "superior compositions" were now "used for the sole aim of gratifying listeners with the amenities of sound" (1969: 242). By then Schoenberg was also complaining about an "amoral, success-ridden materialism ... in the face of which all the ethical preconditions of our art are slowly disappearing." ${ }^{5}$ The American public, in his view, "lets its leaders drive it unresistingly into their commercial racket, and doesn't do a thing to take the leadership out of their hands and force them to do their job on other principles." 6

Faced with such problems, Theodor W. Adorno (now himself an immigrant) went as far as to suggest that Europeans, wishing to become part of American society, liberate themselves from their "naive belief in culture," and acquire "the capacity to see culture from the outside" (quoted in Fleming and Bailyn 1969: 367). What Adorno meant, of course, was that "culture" could no longer be taken for granted; in fact, however, few Europeans were prepared to let go of it. Of particular interest are those refugee composers who, far from relinquishing their heritage, not only held fast to it but were determined to try to share it with Americans by having them understand it better. It was as educators, then, that these composers came to see themselves playing an especially important role in the further development of American musical life. They would appear to the public not only as composers but also as men 
who would speak on behalf of cherished values, and this public would consist of all who could be persuaded to hear them. Ernst Toch, for instance, talked on such questions as "What Is Good Music?" (University of Minnesota, 9 November 1954), cautioning his listeners against the all-too-prevalent over-estimation of technique and style, these being the merely material, timebound manifestations of art, and calling for more awareness of music's timeless, "spiritual" dimensions (see Toch 1955). Hanns Eisler, whose years in America seemed only too vividly to confirm his already long-held belief that the widening gap between serious and light music would inevitably lead to a state of widespread musical barbarism, offered courses at the New School for Social Research, between 1938 and 1942, which were open to laymen and carried such titles as "The Art of Listening" and "Music as a Human Form of Expression." It was Schoenberg, however, who was most active in addressing many different kinds of audiences on a wide range of topics, few of them technical. Just as Toch raised the question of "good" music, so Schoenberg considered it his task to give laymen not only "a real knowledge of basic elements for appreciation," but also "a sound capacity to distinguish between value and non-value."7 A public lecture course he gave at the University of Southern California in 1935 was entitled "The Evaluation of Musical Works" and announced as follows: "a class ... describing, comparing, evaluating, criticizing and judging music. Mr. Schoenberg will provoke direct musical reactions to musical meaning, apart from titles and reputations of composers."

For the just-stated purpose of pulling American audiences away from the publicity orientation of the entertainment business, Schoenberg believed that instruction in critical listening was only a first step. One would also have to strive to counteract the overspecialization and over-professionalization of American musical life, which served the entertainment industry by keeping the public passively in thrall to "star" performers. It is well known, of course, that not a few composers had already tried to deal with this problem in the Europe of the 1920s. Paul Pisk was drawing on his own experience when, in 1944, he proposed to a Los Angeles conference on issues in contemporary musical life that Americans consider the systematic development of amateur music-making among the working class, such as had been put into practice by the Austrian Social Democratic government some two decades earlier (see Pisk 1944). No such centrally organized action turned out to 
be feasible for post-War America, yet many were the refugee composers who would, in any case, respond to the now rapid spread of musical activity across the continent, writing in particular for bands and community opera workshops. The vitality of a nation's musical life, they believed, must be measured by the activity of its amateurs; the mere consumption of amusement-seekers, said Schoenberg, is no substitute for the genuine enthusiasm which amateurs bring to what they do. ${ }^{8}$

While anxious to bring such general concerns to the American public at large, Europeans who received appointments in universities and conservatories came also to be occupied with the particular problems of teaching musicianship, theory, and composition, in a situation for which their earlier experience had not prepared them. Their students, though talented, open-minded, and eager to learn, lacked basic music reading and writing skills such as had been taken for granted in the old country. Consequently, even the more mature students, who already wished to see themselves considered as composers, found themselves being treated little better than rank beginners. At Yale, Hindemith refused, for many years, to deal squarely with the question of composition at all, restricting his students to exercises in the formation of a type of raw material, considered as preliminary to genuine creation. Such material he wished to give the status of objectivity; though not modelled on particular composers or styles, it was seen to stem from tradition and embody its essence. The premises from which the material sprang were therefore not to be questioned or discussed by students. Somewhat similarly Schoenberg devised, for his students in California, exercises which would provide mechanical facility in generating the simplest musical ideas - what he called problemsolving in the absence of inspiration. If, unlike Hindemith, he did have his students analyze masterworks, it was only that they might better see the qualitative differences between imaginative solutions and their own practical exercises. In sum, neither of the two men seemed able, in their American teaching careers, to bring their students to the point of bridging the gap between technique and imagination, craft and art, a failure which they would probably have defended by pointing to circumstances.

Put concisely, what Schoenberg wished to convey to his students was a sense of musical practice, with himself, a masterly practitioner, serving as a kind of model. For that purpose the connection of practice with tradition, as in the case of Hindemith, 
would simply have to be assumed, ruling out (at least for the time being) critical or historical terms of reference. Consequently there disappears just about completely from his American teaching manuals the speculative and conceptual substance of earlier texts such as the Harmonielehre and Der musikalische Gedanke und die Logik, Technik und Kunst seiner Darstellung (left unfinished). Theoretical constructs are now reduced to a bare minimum, while rules for writing music are presented as a distillation of practice. American students, thought Schoenberg, relied in any case too heavily on theories and explanations. If one gives them principles, he complained, they "want to apply them too much 'on principle.' And in art that's wrong ...."9 They should, that is, rather learn from example.

There can be little doubt that the reverence for tradition of Hindemith and Schoenberg was made all the more unyielding by their encounter with American students. Other Europeans, to be sure, took more flexible approaches. Darius Milhaud, to cite an extreme case, wholeheartedly approved of his composition students' creative naïvete and praised, while at Mills College, their happy freedom from inhibition (see Milhaud 1952: 241). Here he was surely revealing his allegiance to Cocteau's call for a demystification of art and the devil-may-care attitudes of French neo-classicism. For those such as Toch and Krenek transplantation sparked, at least, the desire for some fresh thinking about the past and a larger, more critical view of it. Toch, thrown into confusion by frustrating experiences with his students, began to seek ways of freeing the understanding of older music from fossilized "theory" and linking it more closely to contemporary developments. The avowed aim of his Shaping Forces in Music, as he told his patron Elizabeth Coolidge, was to "get the whole immense structure of music into ... focus:" to propose, indeed, something like a universal core of thought which would serve as a starting-off point for young composers of today. ${ }^{10}$ Krenek, like Toch, found that his teaching activity stimulated him to reflect, de novo, on the composer's relationship to the materials that history had bequeathed to him. Impatient to bring his students to the heart of the matter, he cited with approval the recommendation of his predecessor at Vassar College, G.C. Gow, that the teacher reduce to general terms the essential compositional principles of past epochs and then proceed directly to contemporary means of expression (in Gow's case, Wagner; in Krenek's, Schoenberg). Krenek's twelve-tone counterpoint manual, which springs from 
his own interpretation and drastic distillation of melodic elements in medieval music, was intended to provide the basis for a new metier. It was rejected by Schoenberg precisely because it took leave of tradition. Yet insofar as it suggested a method of composition, Krenek's pedagogy was perhaps better suited to American conditions than Schoenberg's, which was rooted nonsystematically in the idea of traditional practice.

Differences, then, among the refugee composers with respect to general outlook as well as teaching principles and approaches should not be overlooked. Where they did seem to see eye to eye was on the question of the composer's role as an educational and cultural leader. The bearing of authority which they brought with them to the new country, and refused to relinquish despite the composer's more humble status in American society, caused no little resentment among American colleagues, who were inclined to see such bearing as a sign of arrogance. Plans for sweeping reforms of university music curricula submitted by Hindemith and Schoenberg were rejected as being incompatible with existing departmental structures, and antagonism was provoked by the attempts of these two newcomers to establish, in the end surreptitiously, an exclusive and hierarchical "school within a school" based on the European model. Students, however, were impressed not only by the sense of discipline which such a model brought with it, but also by the extraordinary responsibility which European teachers took on, as authority figures, for both their musical and personal development. According to the testimony of Lily Toch, her husband found teaching to be exhausting since it meant much more to him than everyday instruction: "In German we say 'He's fighting for his [student's] soul' ('Er kämpft um seine Seele')."1 Similarly, Schoenberg believed that education (as opposed to mere training) should help to develop character and morale. Above all, the composition teacher must give his students "the courage to express what they have to say." 12 Yet courage can only come with the confidence that stems from the capacity to make judgments based on demonstrable technical and aesthetic criteria. Schoenberg's unrelenting restriction of his students' compositions to traditional materials (a concert, given at his own home, by seven of his "advanced" students had each perform a sonata first movement!) was motivated, no doubt, by the desire to implant this secure critical faculty. Hindemith's students, while often frustrated by the severe constraints imposed upon them, were nevertheless grateful to 
their teacher for providing, as several of them put it, something to hold on to. ${ }^{13}$ They may not have necessarily agreed with their teacher's way of extensively re-writing their compositional exercises, so as to "improve" upon them, but it would always be clear why he should want to do it. That one could attach an objective yardstick to something quite as "personal" as composition came as a surprise to Americans, just as, surely, Hindemith's insistence on their developing an understanding of the ethical basis of their calling as composers. He used the term "ethos" to mean the concordance of intention and result which forms the basis of practiced artistry, ensuring that what is produced will not only be fully realizable in performance but convey an immediately comprehensible meaning. By such a standard any striving for originality leads, in the inexperienced hand, to an overshooting of the mark, and can only end with uncertainty and confusion. It was Hindemith's conviction that students trained by him to write "ethically" would be better prepared to ascertain whether they would ultimately be worth anything as composers. Those who did indeed choose to become composers would help raise what he saw to be the existing low standards of musical composition in his adopted country. The others would at least have gained the assured control of musical elements needed for successful careers as teachers or practical musicians.

That a strong grounding in technique was not to be considered an end in itself was made plain by Toch who, in 1948, resigned his position at the University of Southern California, and, in a newspaper interview of some years later, declared that composition, as such, could not be taught (see Goldberg 1954). The storm of protest which this statement provoked among many of his American colleagues was not surprising, since Toch's stand appeared to be extremist. Nevertheless, his essential point, that the teaching of technique was valueless if, in conveying the means, the end was lost sight of, deserved more sympathetic consideration than it received. Far from wishing to lend support to any notion of unspoiled creativity, he intended, rather, to protest against the growing rationalization of the life of the mind concerning which Adorno had become more and more alarmed in observing modern (and especially American) society. Toch's objection to the certification of composers by educational institutions, after the accumulation of the necessary amount of (all too often unconnected) credits, was cut from the same cloth as Schoenberg's rejection of a "system" of teaching; both represented 
attempts to arrest what was seen as a steady erosion of the humanist perspective.

Evidence for the American teaching activities of refugee composers is readily available in the many archival collections, established in the United States and Europe, and the interpretation of such evidence presents no extraordinary difficulties. On the other hand, researchers who wish to investigate America's influence on the careers of these men as composers will have to deal with evidence that is less unambiguous (principally, the music itself), several methodological problems, and, finally, a not particularly favorable climate for their studies. First of all, it is impossible to establish with any degree of certainty that the refugees composed very differently in America, for the obvious reason that we do not know how they would have composed had they remained in Europe (see Krenek 1959: 757). Secondly, in considering grounds for what appear to be changes in compositional direction, it is only too tempting to attribute to environment and circumstance (because these were new) what under more normal conditions could be more readily explained by the ordinary effects of maturing and aging. The general obstacle, never taken seriously enough, is the avant-garde bias which has shaped our view of twentieth-century music to a great degree, and which is antihistorical. Its concern, for one thing, is only with major figures, casting into the dark many whose contribution to music deserves to be more fairly and objectively evaluated; among such obscured figures are indeed those refugees who, while in America, took a more realistic view of opportunities available to them and, in so doing, abandoned the modernist cause. One or two, at least for a while, even gave up composing serious music altogether, and here it should be noted that, in the case of Erich Korngold, opportunism appears to have taken second place to moral considerations: one could not compose while the Nazis were in power. ${ }^{14}$ The second effect of avant-gardism is that even the music of a Stravinsky or Schoenberg has come to be evaluated quite narrowly: that is, only for what it can provide by way of guideposts to the future. When the technical and constructive possibilities of that music become the principal concern, then the oeuvre of the composer comes to be seen as a whole, untouched by the intervention of outside events. It becomes tradition, rather than the object of historical understanding. The historian of the migration phenomenon, on the other hand, should not hesitate to propose for consideration factors which can appear peripheral to intrinsically musical concerns. Here these 
would include not only particular personal circumstances, but also general facets of American musical life which affected the refugees for better or for worse.

To earn a living many of the composers had to take on not only kinds of teaching for which their European backgrounds had not prepared them (and which therefore made especially heavy demands on them), but also hack work of one kind or another. Men like Toch and Eisler, as well as Mario Tedesco and Eric Zeisl, moved to Hollywood in the hope of realizing their vision of a motion picture Gesamtkunstwerk in which music would have an integral part, but were soon disappointed and had to acquiesce in the exploitation of their talents according to the required formula. The struggle for survival was to become a major preoccupation for all but a very few (such as Stravinsky and Hindemith), with only slight relaxation of its pressures after the War. Material hardship, however, was felt to be bearable for as long as an eventual improvement of prospects could be anticipated; more inclined to depress the refugees' spirits was the pervading resistance to contemporary music, far more stubborn than anything they had known in Europe. For the most part neither symphony orchestra conductors (most of them, of course, émigrés themselves), nor broadcasting and recording companies, and least of all publishing houses, could be persuaded to initiate directions that would run contrary to the motive of immediate economic gain. Moreover, in their struggle to persuade musical organizations and institutions to make place for new works, the Europeans had to compete with a generation of native-born composers now reaching maturity and wishing to be recognized as the creators of an original American music. It is true that, to begin with, the better known among the refugees were given a warm welcome, not only by academics, intellectuals and community leaders at large, but also by a handful of composers who hoped to see the newcomers contributing to an enrichment of American musical life. Europe's loss, declared Roger Sessions, would be America's gain, and he called for "a spirit of genuine collaboration and constructive action in building gradually a real and profound musical tradition on our side" (1938: 203). Yet while Sessions rejoiced in a possible end to what he saw as American cultural isolation, there were many others to whom this most recent wave of European influence appeared as a threat to nationalist aspirations. Throughout the War years journals such as Modern Music and the Musical Courier provided a forum for debating the effects of the foreign influx, such as a "leavening" of 
American music. Some writers went as far as to advocate that the number of musicians admitted as immigrants be restricted; others were content to ask only that "obligations to our home-trained musicians" not be neglected (Moore 1941: 94). It is indeed unfortunate that some of the Europeans responded by focusing the argument on the question of standards. Thus Hindemith used the platform of his Norton lectures to brand musical nationalists as those who display "artistic inferiority compensated for by loudness" (1969: 231) and Stravinsky likewise equated American music with lesser achievement (see Stravinsky and Craft 1959: 29-30). Schoenberg, who must be counted among the few newcomers who did come to show a genuine appreciation of native composers, saw himself nevertheless as the "victim" of a movement to "suppress gradually all European composers" while also fearing that, as a result of an Allied victory, Europe would come to be swamped by (implicitly second-rate) American cultural goods. ${ }^{15}$

Despite all efforts to develop broader public interest in his music, the American composer was still not, in Krenek's view, a "living presence" in his community (1938: 27). For this reason alone the refugee composer could not expect that the status he had enjoyed at home would continue to be recognized in the new country. Writing to a friend in Palestine, Schoenberg remarked with amusing irony that, just as frequently performed and just as famous, he must now be considered a truly American composer. ${ }^{16}$ What Krenek called the "Echoloskeit" of the American musical environment, its unresponsiveness to composers, was at least partly responsible for driving some, like Toch, to a state of creative paralysis which stretched through much of the 1940s. For others it meant not silence but significant adjustments and changes of direction. There was now, for sure, a sharper line drawn between the realms of private and public. Included among music composed, so to speak, for the drawers, was Krenek's Lamentations of Jeremiah, its esoteric serial explorations not expected by the composer to attract public attention. There were composers, too, who would write music of an autobiographical or confessional nature: Eisler's Hollywood songs, for example, composed to texts of exile poets both past and present, are on the one hand an expression of viewpoints and experiences which he shared with those poets, and, on the other, an appeal to a German socialist utopia to come, since the composer did not expect the music to mean anything to his American contemporaries. Those composers 
who, whatever their private concerns, did indeed attempt to write for a public, were required to consider genres of composition appropriate to changed circumstances. With Weill as an exception, the common bent of Europeans for opera composition had to be, for the most part, suppressed for being unfeasible. Thus Hindemith, for instance, about to emigrate and inspired by a tour of the Alleghenys, sketched two operas on American themes, but subsequent discussions with the management of the Met quickly convinced him to abandon his plans. Zeisl's projected magnum opus, the opera Job, remained a torso, abandoned precisely at the point where the drama's principal protagonist arrives in America, and both Toch and Tedesco redirected their energies to smaller projects involving student or local community organizations. Similarly, opportunities for larger-scale choral works were restricted to occasional commissions that came to Schoenberg, Toch, and Zeisl from Jewish congregations in Los Angeles. In the main, ambitious plans had to be sacrificed to the composition of smaller instrumental pieces of educational or generally practical value. One had to think of what would "sell."

Krenek somewhat wryly remarked that America had a sobering effect on the Europeans; it sharpened their sense of reality, though at the cost of what the writer Robert Musil had called the "sense of possibility" (1959: 761). They discovered, namely, that general recognition could not be won without an acceptance of circumstances that called for a more straightforward idiom and a more openly communicative manner. Krenek himself put his unperformable Lamentations on the shelf when the conductor Dimitri Mitropoulos wrote to him to suggest that he write music "with more human appeal," following the example of Hindemith, who "with his new symphony [the Symphony in E-Flat] was able to touch and to thrill even a Minneapolis höchst konservativ public." 17 The result of this urging was Krenek's Symphonic Variations on the American folksong "I Wonder as I Wander," with which, as the composer declared, he tried once more "to find a contact with the practicalities of musical life."18 Even Schoenberg began to distinguish between the music he wrote for himself and that composed with a larger social purpose in mind. In the latter category belonged the arrangements, already done, of Bach, Handel, and Brahms, frequent performances of which would (as he hoped) prepare the ground for his acceptance by audiences at large, as well as the works specifically for American performers, composed "progressively" in a conservative idiom in 
order to show up the prevailing brand of reactionary conservatism for what it was. ${ }^{19}$ But even new major works, such as the Ode to Napoleon and the Piano Concerto, show a relaxation of twelvetone constraints and a revival of rhetorical modes of musical discourse: qualities that have already long been remarked upon, but rarely with reference to circumstances of the moment, which were surely of some influence. In addition to those already mentioned, there was the fact that, in a time of world crisis, the need to make oneself understood (where there were still ears free to listen) became more urgent. Toch, having been driven by events to a kind of Nietzschean "revaluation of values," ultimately returned to traditional principles of symphonic writing, through which, he believed, private and public could once more be joined. Beginning with his First Symphony (1949-50), there arises in his music a concern with content, or, to be more precise, a concreteness of expression. The responsible composer, declared Toch, "should confine himself to the really necessary, significant and worthwhile;" he can no longer be satisfied with "the more or less empty toying with sounds, or the repetition of certain fashionable patterns or "isms" that had characterized much new music of the earlier part of the century. ${ }^{20}$ To make what he now wished to say to his audiences more explicit, Toch went as far as to attach programmatic titles to the movements of his symphonies. Not too different was Eisler's motive in answering Brecht's objection to his return to writing absolute music: listeners to Fourteen Ways of Describing the Rain, a major work of his American years, should hear it as reflecting an anatomy of sorrow: "the crucial theme of the twentieth century" (1970: 16).

For Eisler there was also the personal sorrow of one who felt himself as an exile, and other refugees shared that feeling to varying degrees. Indeed in the case of each individual the categories "exile" and "immigrant" overlap in one way or another. Even those who arrived in America disillusioned with Europe (notably, Krenek and Weill) and determined, as immigrants, to make a new life for themselves, were unable completely to shake off the sense of uprootedness, no matter how much they may have tried to hide it from themselves. While few of the refugee composers were not to become, rather quickly, energetic participants in American musical life, all resisted, to some measure, full social and cultural absorption. It is perhaps not surprising, in turn, that American music historians have preferred to treat them as a special group - certainly not as new Americans - and even to 
view their contribution to the country's music with a certain distrust. Gilbert Chase, for instance, has berated the Europeans for holding compositional tenets, whether neoclassical or dodecaphonic, that turned out to be "fundamentally reactionary," thus inviting no commitment to new principles (1966: 605). Hamm has also interpreted the European influence as a setback for the development of a specifically American music. In his opinion, American composers who studied with the Europeans were forced, because their teachers considered them incompetent, to "start from scratch," rather than being encouraged to blend "elements of foreign music with the emerging American musical language" (1983: 562).

In this writer's researches there has appeared not a shred of evidence to show that such students were particularly aware of any emerging language; on the contrary, several complained that their earlier American teachers had given them too little direction..$^{21}$ Europeans would not have believed that any American could consider their music to be "foreign," and not all of them were blind to American musical idioms, even if these, in their view, did not amount to a language. It should also not be forgotten that there were those Europeans, the Korngolds, Steiners, and Roszas (to be followed by their students as well as the students of "serious" composers like Toch and Tedesco) who in the end created an American music, the music of Hollywood motion pictures. As for those teachers who treated their students as beginners, they surely did so only because they were possessed by a sense of obligation to a tradition rendered doubly vulnerable: by the eclipse of the world that had conceived and nourished it, and by the emergence of a new society wishing, after all, to adapt that tradition to its own purposes, but still needing help in order fully to understand its underlying premises. If, finally, the Europeans did not attempt to compose a distinctively American music, nevertheless what they did write while in America reveals particular qualities, and these can be traced to a response at once critical, in upholding traditional standards, and conciliatory, in bringing to light a new found communicativeness and compassion. "America," said Zeisl," can find in my work not her own image mirrored, but ... strong medicines against the ills of fate, which $I$ have learnt to brew and which she may need one day. They are hers" (quoted in Goldberg 1950b). 


\section{NOTES}

1. These are Fermi (1968) and Jackman and Borden (1983). Musicians do not appear in such important publications as Fleming and Bailyn (1969) and Radkau (1971).

2. Letter to Willy Strecker of January, 1947, quoted in Briner (1971):171.

3. In 1950 Goldberg, music critic for the Los Angeles Times, requested from a number of refugee composers their opinion regarding the effects of transplantation on their work. The responses appeared in his Times column "The Sounding Board" on 14, 21 and 28 May of that year. The first of these contained Schoenberg's response.

4. Letter to Oskar Kokoschka of 3 July 1946, in Stein (1964): 242.

5. Letter to Frank Pelleg of 26 April 1951, in Stein (1964): 286.

6. Letter to Rudolph Kolisch of 12 April 1949, in Stein (1964): 270.

7. Letter to Bessie Bartlett Fraenkel of 26 November 1935, in Stein (1964: 195-96).

8. Schoenberg's most clearly expressed views on this matter can be found in an unpublished essay entitled "Some Problems for the Educator," and his remarks on a letter from Edwin Franko Goldman of 17 January 1934. Both items are in the Archive of the Arnold Schoenberg Institute, and are numbered 228 and 169, respectively, in Rufer (1962).

9. Letter to Ernst Krenek of 1 December 1939, in Stein (1964: 210).

10. Letter to Elizabeth Coolidge of 19 January 1942. Ernst Toch Collection, Music Division, The Library of Congress.

11. The Orchestration of a Composer's Life, Lily Toch interviewed by Bernard Galm, Oral History Program, University of California (1978), p. 614.

12. "First American Broadcast," Interview with William Lundell, in the Archive of the Arnold Schoenberg Institute, item number 9 in Rufer (1962).

13. Evidence for this sentiment can be found in the interviews conducted by Caitrona Bolster with Hindemith's American students, these forming part of the Hindemith Project, Oral History, American Music, housed at the School of Music, Yale University. Particularly relevant are the interviews with Henry Kaufman, Lukas Foss, and Norman Dello Joio.

14. According to his son George, Erich Korngold became, at the outbreak of World War II, "a brooding pessimist determined not to compose any absolute music until '... the fiend in Germany is defeated'." See the biographical sketch provided by George Korngold for the recording Elisabeth and Essex: The Classic Film Scores of Erich Wolfgang Korngold, ARL-1-0185 (1983).

15. Letters to K. Aram of 15 November 1947, and Rudolph Kolisch of 12 April 1949, numbered 250 and 270, respectively in Stein (1964). 
16. Letter to Georg Wolfsohn of 4 March 1939, in the Arnold Schoenberg Collection, Music Division, The Library of Congress.

17. Letter from Mitropoulos to Krenek of 25 November 1941, quoted in Zenck (1980: 228).

18. Krenek's journal entry of 22 June 1942, quoted in ibid.

19. In his "Sketch of a Foreword to the Suite for String Orchestra" (not published with the score), Schoenberg distinguished between the unproductive, who have nothing to conserve since they possessed nothing worth keeping in the first place, and the productive who conserve a foundation upon which they may build securely for the future. An English translation of the foreword is given in Rufer (1962: 81).

20. Letter to Harold Spivacke of 8 August 1947, in the Ernst Toch Collection, Music Division, The Library of Congress.

21. The already cited interviews with Hindmith's students are especially revealing in this connection.

\section{REFERENCES}

BRINER, A.

1971: Paul Hindemith. Zurich: Schott.

CHASE, G.

1966: America's Music: From the Pilgrims to the Present. New York: McGraw Hill.

EISLER, $\mathrm{H}$.

1970: Gespräche mit Hans Bunge. Leipzig: VEB Deutscher Verlag für Musik.

FERMI, L.

1968: Illustrious Immigrants: The Intellectual Migration from Europe, 1930-41. Chicago: University of Chicago Press.

FLEMING, D. and BAILYN, B., eds.

1969: The Intellectual Migration: Europe and America, 1930-1960. Cambridge, Mass.: Harvard University Press.

GOLDBERG, A.

1950a: “The Sounding Board," Los Angeles Times, 14 May, Section 4, p. 5 .

1950b: "The Sounding Board," Los Angeles Times, 28 May, Section 4, p. 4.

1954: "The Sounding Board," Los Angeles Times, 24 January, HAMM, C. Section 4 , p. 5 .

1983: Music in the New World. New York: W.W. Norton.

HINDEMITH, P.

1969: A Composer's World. Gloucester, Mass.: Peter Smith. 
JACKMAN, J.C. and BORDEN, C.M., eds.

1983: The Muses Flee Hitler: Cultural Transfer and Adaptation, 1930-1945. Washington: Smithsonian Institution Press.

KRENEK, E.

1938: "The Transplanted Composer," Modern Music, 16/1, 23-27.

1941: "The Survival of Tradition," Modern Music, 18/3, 143-46.

1959: "Amerikas Einfluss auf Eingwanderte Komponisten," Musica, 13, 757-61.

MILHAUD, D.

1952: Notes Without Music. Translated by Donald Evans. London: Dennis Dobson.

MOORE, D.

1941: "Facing the Challenge," Musical Courier, 137/2, 94. PISK, D.

1944: "The Development of an Audience through Workers' Musical Education in Vienna," in Music in Contemporary Life, Papers from the Institute, September 14-17, 1944. Los Angeles: UCLA Music Library Archival and Special Collection, 47-49.

RADKAU, J.

1971: Die deutsche Emigration in den USA. Düsseldorf:

RUFER, J. Bertelsmann Universitătsverlag.

1962: The Works of Arnold Schoenberg. London: Faber.

SESSIONS, R.

1938: "Vienna-Vale, Ave," Modern Music, 15/4, 203-08.

STEIN, E., ed.

1964: Arnold Schoenberg Letters. London: Faber.

STRAVINSKY, I. and CRAFT, R.

1959: Conversations with Igor Stravinsky. Garden City, N.Y.: Doubleday.

TOCH, E.

1955: "What Is Good Music?" Musical Courier, 152/6, 8-10.

ZENCK, C.M.

1980: Ernst Krenek--ein komponist in Exil. Vienna: Lafite Verlag. 